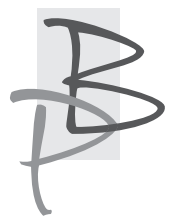

Andrzej Baranow*

Uniwersytet w Białymstoku

https://orcid.org/0000-0003-4787-5384

\title{
Dzieło Antanasa Baranauskasa z perspektywy XXI wieku
}

Streszczenie: Antanas Baranauskas (1835-1902) - klasyk literatury litewskiej, autor arcydzieła Borek Oniksztyński, figura renesansowa, wciąż wzbudza kontrowersje. Perspektywa nowoczesna pozwala w jaskrawym ujęciu wyświetlić jego spuściznę, w tym mało znane utwory literackie, na przykład Podróż do Petersburga. Bilingwizm pisarza przekształca się w polilingwizm i obejmuje całe jego pisarstwo. Na szczególną uwagę zasługuje twórczość polskojęzyczna, w której centrum znajdują się dzienniki. Dzieło Baranauskasa aktualizuje ważne dla czasów współczesnych dyskursy - estetyczny, tożsamościowy, sakralny, lingwistyczny. Potrzebna jest monografia w języku polskim, obejmująca całokształt dzieła pisarza.

Słowa-klucze: nowoczesność, dyskurs, arcydzieło, bilingwizm, tożsamość, diarystyka.

* Andrzej Baranow - dr hab., prof. UwB; kierownik Pracowni Komparatystyki Kulturowej na Wydziale Filologicznym Uniwersytetu w Białymstoku; przez lata pracował na Litewskim Uniwersytecie Edukologicznym w Wilnie (obecnie: Akademia Edukacji Uniwersytetu Witolda Wielkiego w Kownie, oddział w Wilnie). Zainteresowania badawcze: literatura polska XIX wieku, literatura młodopolska, teoria komparatystyki literackiej, litewsko-polskie związki kulturowe w kontekście europejskim, badania genderowe. Opublikował monografię zatytułowaną: Dostojewski i literatura polska (do 1918 roku) (Wilno 2001) 


\section{The work of Antanas Baranauskas from the $21^{\text {st }}$ century per- spective}

Summary: Antanas Baranauskas (1835-1902) - a classic of Lithuanian literature, the author of the masterpiece The Forest of Anykščiai, a Renaissance figure, still sparks controversy. The modern perspective allows displaying his legacy in a vivid way, including little-known literary works, for example "A Journey to St. Petersburg". The writer's bilingualism transforms into polingualism and covers all his writing. Particularly noteworthy are his Polish-language works, especially his diaries. Baranauskas's work brings back relevance to the aesthetic, sacral, linguistic and identity discourses. There exists a need for a monograph in the Polish language that would cover the writer's entire work.

Key words: modernity, discourse, masterpiece, bilingualism, identity.

Pisarz Antoni Baranowski / biskup Antanas Baranauskas (1835-1902) była to bez wątpienia osobowość oryginalna, należąca do rzędu tych, które z rzadka objawiają się w dziejach poszczególnych narodów, pełnią wielką rolę, wyznaczoną im w historii kultury. Wśród współczesnych nazywany bywał często prawdziwą perłą literatury litewskiej. To określenie nie traci znaczenia również w naszych czasach.

Często nazywany bywał on polsko-litewskim patriotą w dawnym, przedstyczniowym stylu, gente Lithuanus, natione Polonus, polonofilem, który uważał, że Litwa powinna funkcjonować w ścisłym sojuszu z Polską. Jest Baranauskas postrzegany jako postać renesansowa, człowiek siedemnastowieczny, ale także jako pisarz wzbudzający kontrowersje. Można bez trudu wskazywać liczne skrajności jego portretu. Przez całe życie pielęgnował język litewski, podkreślając: „Pierwsze promienie prawdy w moim umyśle zabłysły po litewsku; pierwsze drgnienie serca moją pierś po litewsku ogrzały. Mnie mateczka po litewsku kołysząc śpiewała, niania po litewsku bajki opowiadała. Pierwsze pieśni w moim sercu po litewsku brzmiały"1.

\footnotetext{
1 Za: R. Mikšytè, Antano Baranausko kūryba, Vilnius 1964, s. 197.
} 
Pisarz urodził się w Oniksztach (Anykščiai), centrum etnicznej Litwy. Jego ojciec, Jan Baranowski, wywodził się z wolnych chłopów królewskich. Pracował w zarządzie gminnym jako urzędnik. Oprócz litewskiego znał języki polski i rosyjski. W rodzinie rozmawiano głównie po polsku, w odmianie regionalnej, poza domem zaczynał dla Antoniego działać bilingwizm podwórkowy, pozwalający przełączać się na język litewski, który był w nim genetycznie zakodowany.

Nauczyciel szkoły podstawowej prorokował mu sławę albo katorgę. Przyszły pisarz lawirował na krawędzi przepaści i pozostawał zagrożony karą katorgi przez całe życie. Rok 1863 zapisał się w jego pamięci traumatycznie. Spalił wszystkie papiery powstałe w tym okresie. Carskie dokumenty archiwalne świadczą o tym, że władze uważały Baranauskasa za człowieka niebezpiecznego. Przeniesienie go do Sejn traktować należy jako wygnanie. Baranauskas przez całe życie w kontaktach z władzą był cavendo tutus, uparcie trwając przy własnych poglądach.

Jak wyglądają osoba i twórczość Baranauskasa z perspektywy nowoczesnej? To pytanie wywołuje mnóstwo komentarzy. Znamy pisarza przede wszystkim jako autora poematu Borek oniksztyński (Anykščiu šilelis, 18581859). W wieku dziewiętnastym, ponurym dla Litwy, w czasach trudnych dla rozwoju kultury litewskiej, nieznacznie, choć zauważalnie mu się powiodło. Mam na myśli recepcję Borku w okolicznościach wyjątkowo niesprzyjających dla piśmiennictwa litewskiego. Tekst został podpisany pseudonimem Jurkštas Smalauskas i opublikowany przez Laurynasa Ivinskasa w kalendarzu dla ludu. Później wydano go w Pradze za sprawą czeskiego filologa Leopolda Gejflera. Następnie wydrukowany został w Weimarze w opracowaniu Hugo Webera. Była to pierwsza publikacja pełnego tekstu w wersji dialektalnej, przybliżonej do dopiero formułującego się litewskiego języka literackiego. Komentarze i wypowiedzi dziewiętnastowieczne i późniejsze mają w sobie moc kreatywną, dlatego warto dokonać nowego, aktualnego odczytania wypowiedzi Maironisa, Antanasa Vienuolisa, Juozapasa Albinasa Herbačiauskasa i innych krytyków.

Z perspektywy XXI stulecia otwiera się ciekawa panorama recepcji całej twórczości pisarza w wieku XX w tak zwanej Litwie Radzieckiej. Utwory były znane i czytane, obecne w podręcznikach i antologiach. Borek zajmował ważne miejsce w kompendiach dla szkół z polskim językiem nauczania. Profesura „starej daty" wniosła cenny wkład do klasycznej interpretacji dzieł Baranauskasa. 
Warto tutaj wymienić następujące nazwiska: Vytautas Kubilius², Viktorija Daujotyte $\dot{e}^{3}$, Regina Mikšyte ${ }^{4}$. Stworzyli oni syntezy pozbawione naleciałości ideologicznych, lecz zdecydowanie skierowane w stronę poetyki. Literatura i literaturoznawstwo litewskie czasów sowieckich starały się dokonywać rekompensaty wartości tłumionych przez oficjalną ideologię. W powszechnym użyciu był język milczenia i niedomówień. Warto podać jeden z przykładów: utwór patriotyczny Podróż do Petersburga (Kèlionè Peterburkan, 1859), choć zakazany w czasach zniewolenia, był doskonale wszystkim znany i chętnie cytowany, istniał w aluzjach intertekstualnych.

Wiek XXI wprowadził nowoczesne narracje zarówno w badaniach całej literatury litewskiej, jak i poszczególnych utworów Baranauskasa. Odrzucono esencjonalizm, zaczęto akcentować polifonizm kultury. Chciałbym zwrócić szczególną uwagę na dwie pozycje książkowe, dotyczące Baranauskasa: Egidijusa Aleksandravičiusa ${ }^{5}$ i Pauliusa Subačiusa ${ }^{6}$. Pierwsza rozszerzyła przestrzeń badawczą, bo była pisana przez historyka. Druga, filologiczna, zawiera ciekawe, choć dyskusyjne fragmenty. Zaakcentowana jest w niej ekspresywność osobowości Baranauskasa. Monografia Subačiusa składa się z czterech rozdziałów: Hermeneutyka osobowości, Znaczenie utworów, Tekstualność „Borku oniksztyńskiego”, Granice nowych wydań. Autor bada spuściznę Baranauskasa od strony funkcjonalności tekstów, co stanowi novum w odniesieniu do wcześniejszych interpretacji. Zastanawia się on nad takimi aspektami, jak sens dzieł pisarza, kod bibliograficzny i kod lingwistyczny tekstów. Podłączone są tutaj dwa konteksty: filozoficzny i sakralny. Opisane zostały mało znane strony działalności kościelnej pisarza. Rozprawa stanowi studium polemiczne wobec już istniejących syntez historycznoliterackich i prowokuje dyskursy polemiczne do własnej opcji badawczej.

Warto zatrzymać się przy najsłynniejszym utworze Baranauskasa - Borku oniksztyńskim. Przetłumaczony został on na język polski dosyć późno, bo

2 V. Kubilius, Antanas Baranauskas ir lietuviu poezija, „Literatūra ir kalba“ 1986, t. 19, s. 13-19.

3 V. Daujotyte, A. Baranauskas - lyrikas, „Literatūra ir kalba”, t. 19, s. 47-57.

4 R. Mikšytè, Antanas Baranauskas, Kaunas 1983.

5 E. Aleksandravičius, Giesmininko kelias, Vilnius 2003.

6 P. Subačius, Antanas Baranauskas, Vilnius 2010. 
dopiero w roku 1909, przez Stefanię Jabłońską. Tłumaczka w liście do siostry podkreślała: „To Borek się nie spodobał? Biedni Litwini. A oni uważają go za arcydzieło"7. Ten ograniczony, spłaszczony sposób odbioru dominował w początkowym okresie, lecz obecnie stracił zupełnie na wartości, stając się pożywką dla burzliwych, interesujących dysput podczas kolokwiów uniwersyteckich. Dziś Borek zestawia się z Panem Tadeuszem, waży każde słowo, każde stwierdzenie. Co szczególnie ciekawe: paralele obu arcydzieł dostrzegalne są nie tylko w scenie grzybobrania czy w opisach lasów litewskich. W utworze Baranauskasa pojawia się nawet samo nazwisko Mickiewicza.

Warto wziąć pod uwagę osąd Jonasa Basanavičiusa, zgodnie z którym opisy przyrody są w Borku piękniejsze od Mickiewiczowskich. W procesie rywalizacji z autorem Pana Tadeusza zaktywizowały się raczej odmienne narracje mentalne na wysokim poziomie estetycznym, w czasach, kiedy literacki język litewski dopiero powstawał. Baranauskas chętnie i obficie czerpie $\mathrm{z}$ bogatych zasobów litewskiego folkloru. Jego wiersze weszły w sposób naturalny do folkloru współczesnego. Borek eksponuje nie tylko geografię i kulturę Litwy, lecz także filozofię i mądrość ludową. Właśnie ta warstwa semantyczna jest rozwinięta w stopniu ponadprzeciętnym.

Dla Baranauskasa bardzo znaczący był potężny, okazały pejzaż Litwy pogańskiej, obyczaj dawnych Litwinów. W utworach Mickiewicza i Baranauskasa ujawniły się różne struktury artystyczne. Borek przypomina symfoniczny utwór muzyczny. Arcydzieło literatury litewskiej ciągle otwiera nowe konteksty interpretacyjne. Jako przykład może służyć teza Skirmantasa Valentasa, że przedstawiony w poemacie wątek niszczenia lasu jest opisany niezwykle obszernie, obejmuje co najmniej cztery pokolenia ludzi i przypomina cztery wieki upadku ludzkości w Metamorfozach Owidiusza8 ${ }^{8}$.

Borek przesłania inne utwory Baranauskasa, potrzebujące „odkurzenia” przy pomocy nowoczesnej metodologii. Mam na myśli szczególnie przywoływaną już przeze mnie Podróż do Petersburga. Rzecz jasna, to tekst o wydźwięku antymoskiewskim i ,antymoskalskim”. Poetyka i motywy eschatologiczne utworu mogą naprowadzić na rozmaite interpretacje. Podróż

7 Za: M. Jackiewicz, Literatura polska na Litwie XVI-XX wieku, Olsztyn 1993, s. 142.

8 S. Valentas, Anykszczu szilelys - Rytu Lietuvos tekstas: Šventumo erdvè, [w:] Lingvistinis pasaulis poezijoje, Vilnius 1997, s. 70. 
do Petersburga odzwierciedla kardynalne dla dzieła Baranauskasa toposy metafora drogi, występująca pierwotnie w Dzienniku, motyw tłumienia kultury litewskiej przez władze carskie. Dzieło to powinno być interpretowane w kontekście całej działalności pisarza. Jest ono pierwszym utworem literatury litewskiej, mocno nasyconym sakralnością w formie otwartej i powiązanej z motywem ojczyzny. Paulius Subačius przekonuje:

Godne uwagi jest to, że bezkresne Imperium Rosyjskie staje się metonimią dla syna Północy - jednoosobowym symbolem zła. Przy pomocy uogólnienia tworzony jest symbol złych sił, którego tradycja prowadzi do dwudziestowiecznej poezji zesłańczej. Ona ma uwypuklić uczucia religijno-narodowe9 .

Podróż do Petersburga zawiera mnóstwo nieodkrytych tajemnic.

Z perspektywy nowoczesnej należy spojrzeć inaczej na polskojęzyczną spuściznę Baranauskasa, liczącą w sumie około 90 utworów. Piśmiennictwo w języku polskim jest wielowarstwowe i składa się z utworów artystycznych i paraliterackich, w tym Dziennika i licznych listów, adresowanych do osób bardzo zróżnicowanej rangi. Pisarstwo polskie na początku drogi twórczej miało bardzo skąpe i ograniczone źródła - przypadkowe utwory z zasobów bibliotecznych, a także nasycona lituanizmami i rusycyzmami, daleka od polszczyzny normatywnej rozmowa z kolegami-kanclerzystami czy z osobami duchownymi.

Przy omawianiu twórczości Baranauskasa w języku polskim trzeba pozbyć się błędnych tropów. Powinny występować tutaj osobne kryteria. Przyszły biskup litewski z przyczyn obiektywnych nie był zanurzony w polskiej tradycji literackiej, małymi krokami kreował swój indywidualny, oryginalny zmysł estetyczny. Biorąc pod uwagę punkty styczne w twórczości polskojęzycznej i litewskiej, młodzieńczej oraz dojrzałej, można zgodzić się z myślą Subačiusa, że istotnymi cechami poetyki autora Borku były nawiązania do Oświecenia i romantyzmu ${ }^{10}$. Baranauskas debiutował w języku polskim. Ten język był obecny w całym jego dziele, współkształtował on w pewnym sensie

10 Tamże, s. 89. 
litewskojęzyczną twórczość. Bilingwizm pisarza można określić jako naturalny, wzmacniający jego estetykę.

Polskie utwory pozbawione są wyszukanych tropów, wykwintnej stylistyki, składają się jednak na oryginalne zjawisko literackie. Powstałe w języku polskim wiersze Baranauskasa nadają się do przejrzystej klasyfikacji, z wyodrębnieniem poszczególnych cyklów. Próbę interpretacji wymienionych utworów zawiera artykuł Mieczysława Jackiewicza z 1997 roku. Polski badacz proponuje następujące cykle i dominanty: utwory okolicznościowe, wiersze skierowane do rodziny, utwory o stronach ojczystych, opiewające piękno i potęgę przyrody, przemyślenia moralno-filozoficzne i religijne ${ }^{11}$.

Osobno należy zaakcentować pisany po polsku Dziennik Baranauskasa. Nawet dotychczas nie są w pełni przebadane cechy estetyczne tego utworu. Zaskakuje, że były one analizowane tylko od strony lingwistycznej. Mam na myśli głęboką, wyczerpującą rozprawę profesor Haliny Karaś. Język diarystyczny jest interpretowany na poziomach: fonetycznym, leksykalnym i gramatycznym. Badaczka słusznie stwierdza:

Polszczyzna Dzienników Antanasa Baranauskasa reprezentuje XIX-wieczną odmianę terytorialną języka polskiego używaną na Litwie z uwagi na pochodzenie autora i czas ich powstania, a dokładniej regionalną polszczyznę kowieńską. Fakty językowe osobliwe w świetle współczesnej normy ogólnopolskiej, w nich występujące, to zatem cechy oryginalne, często żywe do dziś w polszczyźnie na Litwie oraz zjawiska charakterystyczne dla języka polskiego połowy wieku XIX12.

Dla pełnego odczytania pamiętnika powinien być stworzony odpowiedni klucz interpretacyjny. Tylko na pozór jest to bowiem suchy tekst memuarystyczny. Już na pierwszych stronach zawiera on wyraźną ekspresję artystyczno-egzystencjalną. Pierwsze linijki Dziennika wskazują na specyficzny wymiar tego utworu - głęboko egzystencjalny:

11 M. Jackiewicz, Polskojęzyczna twórczość biskupa Antanasa Baranauskasa, „Acto Polono-Ruthenika" 1997, nr 2, s. 221.

12 H. Karaś, Uwagi o polszczyźnie „Dzienników”(1853-1856) Antanasa Baranauskasa, „Archivum Lithuanicum” 2004, s. 177-178. 
Dzisiaj skończył się rok mojego życia osiemnasty, ale jakaż to dla mnie pamiątka! Gdy cofnę moją myśl wstecz, czyli w czasy przeszłości na lat osiemnaście, nie było mnie wtenczas na świecie, ja świata nie znałem, a on mnie, jednakże świat był kwitnącym beze mnie, równie jak teraz, gdy ja zajmuję małą jego część i liczę się istotą rozumną, na obraz Boży stworzoną. Wieku swego niemowlęctwa nie pamiętam i tylko pierwsza chwila błyska w mej pamięci: gdy rodzice moi mawiali mi, że „rok czwarty mi się skończy” i od tego czasu pamiętna mi każda życia mego chwila i tok czternastu lat życia mego zostaje cały wyryty w mej pamięci, którego i sam czas nie zdoła zatrzeć i wyniszczyć. - Lecz cóż z tego, że ja żyję na świecie, gdy nie czuję żadnej słodyczy życia? - Czytam poezje i inne utwory ludzkiego geniuszu, gdzie często wspomina o szczęściu na tej ziemi i w tym świecie, o szczęściu nieporównanym, o szczęściu, którego ja nie widzę na tej ziemi, bo nie ma [... $]^{13}$.

Ogólna tonacja pierwszych stron Dziennika jest raczej pesymistyczna („Niedziela - byłem w kościele - niepewny jestem przyszłości swojej”"14), co powinno, zdawałoby się, kontrastować z witalnością lat młodzieńczych. Antoni szuka rozwiązania problemów uniwersalnych. Łączy ten proces z sytuacjami intymnymi i konkretnymi wydarzeniami, nawiązuje do znanych określeń kulturowych - życie traktuje jako sen (,sen prędko mijający”).

We wstępie do Dziennika akcentuje myśl dla niego oczywistą:

Więc sam sobie winszuję nastania roku dziewiętnastego, i życzę sobie zdrowia, cielesnego, moralnego, czyli umysłowego i dusznego. - Życzę sobie szczęścia, ale nie tego szczęścia doczesnego, ale owego szczęścia wiecznego, po ukończonej pielgrzymce wygnania naszego - życzę sobie woli duszy, czyli władzy umysłu nad sobą samym, nad swymi namiętnościami i żądzami. - Ale to dzieło jest nad siły moje przyrodzone, a zatem wątpiąc o wykonaniu tego, biorę na ten rok wiarę mocną za przewodnika i wzywam Cię, o Boże! byś raczył mię płaszczem swojej dobroci osłonić, od wszelkiego ochraniać złego i wspierać twoją ręką we wszelkich dolegliwościach i natchnieniem zawsze na dobro naprowadzić. Amen ${ }^{15}$.

13 A. Baranauskas, Raštai VII/1, Vilnius 2003, s. 5.

14 Tamże, s. 16.

15 Tamże, s. 6. 
Jedno z centralnych miejsc pamiętnika stanowi dekalog, zbiór zasad ułożony z myślą o samodoskonaleniu się, gdyż osiemnastolatek bardzo krytycznie oceniał swoją kondycję duchową. Wprowadza zatem pewne auto-ograniczenia, wyrzeczenia, które służą ćwiczeniu duszy i ciała. Podajmy dla przykładu kilka przykazań:

2) Nie pić wódki i innych mocnych trunków; bo one osłabiając umysł, zatępiają go i człowieka czynią podobnym zwierzęciu, na koniec naciągają choroby rozmaite i śmierć niewczesną,

3) Nie palić żadnego rodzaju tytuniu, gdyż to obciąża piersi, niepotrzebny przynosi wydatek i jest źrzódłem suchot.

4) Zachować ścisłą dyetę, gdyż obfitość potraw obciąża żołądek i umysł czyni niezdatnym do pracy.

5) Zachować milczenie - gadając tylko tyle, ile przyrodzona potrzeba będzie wymagała $[. .$.

6) Zachować porządek w jedzeniu [...] nigdy [...] nie podziękowawszy Panu Bogu za jego dary ani przystępować ku posiłkowi, ani odstępować od niego.

7) 0 jednej co dzień porze wstawać, wstawszy oddać cześć najwyższej Istności za zachowanie przy życiu nocy przeszłej, [...] zostający od obowiązku czas obrócić na czytanie użytecznych ksiąg [...]

8) Z żadnym człekiem lub kolegą [...] nie zaprowadzać kłótni, przykre od drugiego słowo cierpliwie znieść [...]

9) O nikim nigdy źle nie gadać [...]

10) Najwięcej wystrzegać się kłamstwa [...] $]^{16}$

Czyż nie można owych wytycznych uznać za aktualne również dzisiaj? Miłą niespodziankę stanowi to, że dekalog zamieszczono obecnie (oczywiście, w języku litewskim) w sakralnej, sąsiadującej ze świecką, przestrzeni w Oniksztach. Można zobaczyć go na tablicach znajdujących się obok pomnika Antanasa Baranauskasa, w pobliżu kościoła pod wezwaniem św. Mateusza Ewangelisty. A zatem biskup Baranauskas nie ustaje w misji ewangelizowania zarówno swojej małej ojczyzny, jak i całego świata.

16 Dz. cyt., s. 8-9. 
Notatki dziennikowe powiązane są, oczywiście, ze świętami religijnymi, składającymi się na rok liturgiczny. To nie tylko Boże Narodzenie i Wielkanoc, ale także uroczystości pomniejsze (Gromniczna, Zwiastowanie, Zesłanie Ducha Świętego i inne). Święta w pewnym sensie miały podobne znaczenie w kreowaniu przestrzeni utworu jak w Chłopach Władysława Reymonta. To swego rodzaju fixum locum dzienników pisarza. Przeżywanie świąt jest dla Baranauskasa okazją do odnowienia przyrzeczeń zawartych w sformułowanych dla siebie przykazaniach. Rejestrowanie spraw codziennych, bytowych przerywane jest nierzadko słowami modlitw bądź aktów strzelistych:

Przyjdź Duchu Święty, oświeć rozum nasz, zapal serca nasze, abyśmy idąc drogą prawdy, to wszystko, co się odnosi do chwały Twojej // [34r] i zbawienia naszego mogli dobrze pojąć i podług tego życie nasze urządzić przez Chrystusa pana naszego. Amen ${ }^{17}$.

Istotną cechą Dzienników jest jądro estetyczne, na które składają się powstające na świeżo wiersze. Baranauskas przyznaje, że zaczął pisać wiersze w 1849 roku. Będąc młodzieńcem, pozwalał sobie na dość jeszcze naiwne eksperymenty artystyczne. Przykładem może być wierszowany list do rodziców, z którymi był związany emocjonalnie:

\author{
Najukochańsi Rodzice Dobrodzieje \\ Jam jest od was oddalony \\ I z swej strony wyrzucony \\ Od ukochanej matki \\ I od rodzinnej chatki \\ I od ojca kochanego \\ I od brata rodzonego itd. ${ }^{18}$
}

Warto podkreślić, że tekst Dzienników odzwierciedla sam mechanizm tworzenia wierszy, powolną ewolucję warsztatową artysty i pewne osiągnięcia po-

17 Tamże, s. 31.

18 Tamże, s. 23. 
etyckie. Został tu zamieszczony jeden z pierwszych żartobliwych dziecięcych juweniliów:

\author{
Upłynął Luty \\ A ja tu w Kownie \\ Znosiłem buty \\ Chodząc w szynkownie \\ Albo do miasta \\ Kupować ciasta ${ }^{19}$.
}

Już we wczesnych utworach można rozpoznać mgliście zarysowane kontury przyszłego arcydzieła literackiego, jakim będzie napisany w języku litewskim Borek oniksztyński:

Marzec stopił wszystek śnieg

Rzeki z więzów puścił -

Te przeskoczyły swój brzeg

Jam się w drogę puścił. -

Mróz i z błotem przeplatany

W drodze mię zmęczyły

Radość z smutkiem na przemiany

Duch mój wycieńczyły -

,- -

Skowroneczek rano wstaje

I słońce dogrzewa

Śpiewem ptasząt brzęczą gaje

Pękają się drzewa

Natura ze snu powstaje

Twardego radosna

Wdzięku i czucia dodaje

Wraca się nam wiosna

$-,,-$

Lecz ja wiosennej godziny

19 Dz. cyt., s. 15. 


\section{Zimą przywalony \\ Nie czuję bo od rodziny \\ Jestem oddalony ${ }^{20}$}

Ciekawym wątkiem badawczym może być zestawienie opisów przyrody tego samego autora, tworzonych w językach polskim i litewskim. Przywołajmy jeszcze jeden wiersz, w którym występuje już niemal tonacja Borku:

\author{
Upłynął kwiecień łagodny \\ Jak Zefira Tchnienie \\ I choć jeszcze trochę chłodny \\ Ale ptasząt pienie \\ I brzęczenie kiedy pszczółka \\ Oblatując krzewy \\ Zbiera miód z każdego ziółka \\ I pasterzów śpiewy
}

Widok słońca w rannej porze

I gdy się zatoczy

Rozlewając jasne zorze

Jakże jest uroczy

Śpiew słowików, świst jastrzębia

I zieloność gaju,

Mruk turkoczów i gołębi

Szemrzenie ruczaju ${ }^{21}$.

Wiersze pisane w języku polskim wzmacniają w pewnym sensie związki z poematem Donelaitisa Pory roku (Metai). Łączy utwory podobna metaforyka, kluczowe słownictwo (obraz słońca, pełniący różne funkcje, w zależności od „koła czasu”), a także dynamika opisów i plastyczne obrazki.

20 Tamże, s. 20.

21 Dz. cyt., s. 22. 
O! pośle Nowego Roku

Pierwszy jego sługo!

Nurzasz w przeszłości pomroku -

Bawiłeś niedługo.

$-,,-$

Styczniu mroźny, styczniu chłodny

I śniegiem zionący

Zatem dla nas niewygodny

Zatoż piec gorący. -

$-,,-$

Więcej teraz ma słodyczy

Niżeli wśród lata

Siędziem wszyscy jak na smyczy. -

Ale milsza Chata //

$-$,

[4r] Niźli wieczorne przechadzki

Po lesie po śniegu

Gdzie mróz rozstawił zasadzki

Czatując przy brzegu... -

$-,,-$

Lepiej w cieple sobie siedzieć

W chacie przy kominie

Niźli się na pola biedzić

Gdzie niejeden ginie -

$-$,

Huczą wichry rozszumione

Lecąc przez doliny

Me serce smutkiem ściśnione

Tęskni do rodziny. - 22

Dziennik należy traktować jako mapę XIX-wiecznej rzeczywistości Litwy etnicznej z mocnym podłożem topograficznym. Wnikliwy obserwator, zanurzony w codziennych wydarzeniach, plastycznie przedstawia miejscowości

22 Dz. cyt., s. 56-57. 
znane albo te, o których się tylko słyszało. Cenny materiał stanowią opisy konkretnych wydarzeń, z dzisiejszego punktu widzenia nieodwołalnie pochłoniętych przez historię, na przykład opowieść o wylewie Niemna albo pożarze. Autor umiejętnie operuje takim chwytem literackim, jak kontrast. Miasteczko Wojnuty jest prezentowane w sposób łagodny, sakralny:

Całe miasteczko spokojne, słońce zachodzi i blask promieni odbija się od złotych buław Krzyża na wielkiej wieży kościelnej podwyższonego, który zdaje się, iż panuje nad tym miastem, drzewa koło kościoła, ślicznie zieleniejąc się, formują ze swoich wspólnie plecionych gałęzi śliczny wianek przybytkowi Boskiemu. Mieszkańcy weseli, przechadzając się, używają wolnego powietrza tak, aż me zmysły w zachwyceniu przedstawują sobie jakoby rajskim miastem ${ }^{23}$.

Opis pożaru na tym tle nabiera mocy wielkiej katastrofy, przestrzeń groźnie się psychologizuje:

O Boże! co za okropność! Któż może to zdarzenie doskonale wyrazić, co za lament mieszkańców, krzyk kobiet, płacz dzieci... Już drugi się spalił - trzeci czwarty - piąty - dziesiąty, o Stwórco Najwyższy, nie ma pięciu minut, a całe miasto w płomieniach, ludzie uciekając, niektórzy płomieniem zostali skaleczeni... Krzyże stojąc nad cały miastem i okryte płomieniem, zdają się wyrzucać całemu miastu przednie ich grzechy, za które ich tak Pan Bóg karając, tak daleko karę posunął, iż i przybytek swej chwały jako jedyną ich ucieczkę odbiera, i chwiejąc się, zdaje żegnać zebrany lud na to łzawem okiem i rozpaczającym sercem patrzący 24 .

Egzystencjalny wymiar dzienników przekazuje ponadczasowe refleksje, określające osobowość młodego Baranauskasa.

Tęsknota - z lat dziecinnych wielkie pojęcie wprawiało mię w dumania i wzbudzało tęsknotę, która za oddaleniem się od rodziny coraz zwiększa się. - pochodząca już to z niedopiętego doczesnego zamiaru; już to do rodziny przywięzując

23 Tamże, s. 28.

24 Tamże. 
serce; a najwięcej jakaś niepojęta; ciągnąca me serce - gdzie? - z natężeniem rozumu nie mogę wyśledzić; już to doczesnej pragnienie po śmierci sławy, albo do Niebieskiej dziedziny, a ta jest najwięcej rozrzewniającą osobliwie ogarnia mię w miłych wieczorach w pogodnych nocach i w letnich porankach przed wschodem słońca wciskając mi w głowę - naturę - Boga wiarę - miłość - nadzieję - wieczności nagrodę i karę - i rozrzewnia mię i gwałtem wyrywa z piersi westchnienie, lub ze źrzenicy słodką łzy rosę wyciskając, skrapia mi oblicze 25 .

Dzienniki ujawniają niezwykły talent diarysty, na plan pierwszy wysuwając proces jego psychicznej krystalizacji. Sam autor w unikalny sposób przywiązuje swoje powoli dojrzewające i znienacka wybuchające zdolności do konkretnych dat.

Muzyka - w 1849 uczyłem się na klawikorcie sam przez się, 1850 na skrzypcach, 1853 na gitarze i harmonice, lecz w żadnej nie jestem doskonałym. -

Malarstwo - zacząłem w 1853, lecz nie mając wzorów, nie mogłem się wydoskonalić. -

Pisarstwo - z 1853 zaczynam przez to się żywić - 26

Na łamach notatek diarysty zaczyna działać scalająca dzieło Baranauskasa kategoria pamięci: „W 1838 roku pamięć wzięłem, odtąd wszystko pamiętam”27.

Na samym początku drogi twórczej autor Borku znalazł się w sytuacji paradoksalnej: podejmując się niezwykle złożonych i ambitnych wyzwań, boleśnie przeżywał warsztatowe, językowe potknięcia związane ze słabą znajomością polszczyzny. Zwierzał się na łamach Dziennika, że przelewa na papier myśli stylem prostym i grubymi, niedobranymi wyrazami. Nazywał siebie nieukiem ${ }^{28}$.

Polskojęzyczna twórczość Baranauskasa przynosi dla współczesnego badacza pewien problem translatorski. Próby tłumaczenia tych tekstów na język litewski należy uznać za nieudane, bo nie odzwierciedlają specyfiki polszczyzny dziewiętnastowiecznej.

25 Dz. cyt., s. 27.

26 Tamże.

27 Tamże, s. 26.

28 Tamże, s. 25. 
W Dzienniku działa energetyczna i pulsująca przestrzeń. Zaletą tekstu jest warstwa psychologiczno-estetyczna. Przedstawiona jest w nim wiwisekcja duszy głównego bohatera, a sam tekst może być interpretowany w zestawieniu z diarystyką innych pisarzy.

W wielu tekstach interpretacyjnych ciągle powtarza się myśl, że do przejścia na język litewski zachęciła Baranauskasa Karolina Praniauskaitė. Pisał on po zawiązaniu z nią znajomości wyłącznie po litewsku. Może się to jednak okazać niezupełnie prawdą. Potrzebne jest szersze spojrzenie na zjawisko bilingwizmu, a zarazem terminologiczne uściślenie. Język polski przez całe życie poety objawiał się w przeróżnych formach ekspresywnych. Zajęcia w szkole parafialnej w Oniksztach odbywały się w języku polskim. Biblioteka Seminarium Duchownego w Worniach posiadała bogaty wybór książek. Wnikliwie studiował on Dzieje narodu litewskiego Teodora Narbuta, Historie Polski Joachima Lelewela, Obraz Litwy Józefa Jaroszewicza. Zauroczony był opowieściami historycznymi Józefa Ignacego Kraszewskiego. Pierwsza jego praca lingwistyczna $O$ mowie ludu żmudzkiego i litewskiego powstała w języku polskim. Tłumaczył z polskiego pieśni religijne, przełożył popularną pieśń Boże, coś Polskę..., która była znana też na Litwie.

Korekty wymaga samo pojęcie bilingwizmu u Baranauskasa. To co najmniej trójlingwizm w przestrzeni wielojęzycznej. Język rosyjski znał pisarz od dzieciństwa, ściśle związany był przez całe życie z Petersburgiem. W języku rosyjskim powstała w 1898 roku jego rozprawa naukowa Заметки о литовском языке и словаре. Posługiwał się też innymi językami w swojej korespondencji. Dyskurs lingwistyczny dzisiaj jest jednym ze znaczących elementów przy omawianiu jego dzieł. Często, badając pozostałą po nim spuściznę literacką, natykamy się też na dyskurs tożsamościowy (dwuszczeblowość). Zbliżał się Baranauskas w swoich poglądach do Michała Römera, Ludwika Abramowicza, a także Jerzego Matulewicza (Jurgisa Matulaitisa). Wzbudzał emocje na fali odrodzenia Litwy w latach dziewięćdziesiątych. Obecnie wart uwagi jest też dyskurs polityczny. Jego stosunek do krajowców, ruchu młodolitewskiego na początku XX wieku był niezwykle złożony: Baranauskas miał podwójną tożsamość twórczą w czasach, gdy akceptowano wyłącznie jedną.

O „mickiewiczowskości” Baranauskasa można mówić przede wszystkim w ujęciu głęboko estetycznym. Łączy pisarzy zaskakująca paralela biograficzna: uczucie autora Borku do Karoliny Praniauskaite i Mickiewicza do Maryli. 
Zdaje się, że było to coś znacznie więcej niż zwykła przyjaźń. Baranauskas jako poeta rywalizował z Mickiewiczem w swym Borku. Natomiast ślady wpływu autora Grażyny występują w litewskiej „marsyliance”, czyli Podróży do Petersburga; poeta nawiązuje do III części Dziadów w: Drodze do Rosji, Przedmieściach stolicy. Autor Borku miał wielkie plany translatorskie: chciał między innymi przetłumaczyć całego Pana Tadeusza na litewski. Znany jest współcześnie tylko przekład Inwokacji. „Mickiewiczowskość” z całą pewnością potrzebuje dalszego odczytania.

Baranauskas to „człowiek renesansu”. Pracował po trzynaście godzin dziennie, pisał arcydzieła. Popularna jest jego teza, że prawdziwy naukowiec-językoznawca powinien znać niemal wszystkie starożytne języki, takie jak na przykład sanskryt, perski, celtycki, ormiański i wiele innych ${ }^{29}$. Czy to nie wyzwanie także dla współczesnego badacza?

Od dzieciństwa Baranauskas zdradzał zdolności matematyczne i muzyczne. Od pięćdziesiątego roku życia zaczął się na poważnie interesować matematyką. Można to interpretować jako swoistą ucieczkę od przepełnionej polityką rzeczywistości oraz sposób na zachowanie elastyczności umysłu. Ten okres trwał około dziesięciu lat i wydał swoje owoce. Mogą nas jeszcze czekać zaskakujące odkrycia archiwalne.

Z kolei zainteresowania muzyczne przewijały się przez całe jego życie. Już w roku 1858 w liście do proboszcza Ambraziejusa Kašarauskisa przyznawał się:

Uiszczam się z przyrzeczenia o napisaniu nut pieśni ludowych śpiewanych w okolicach Rzeki Świętej, szczególniej w Oniksztach. Nie są te melodye tak dokładne, jak je śpiewa młodzież litewska. [...] Do dwóch piosenek napisanych Panu załączam obecnie wyjątki kilku innych pieśni, które ze względu na rozmaite porównania, już to do drzew i gwiazd, już to ze względu na opisy przypominające z pewnością Dunaj, morze, rozległe narodowe stosunki, mogą służyć do uwag historycznych tego narodu, tem bardziej, że pieśni te nie są płodem żywej wyobraźni, a wyrosły z faktów, z rzeczywistości [...] $]^{30}$.

29 Zob. Z. Zinkevičius, Antanas Baranauskas kalbininkas, „Literatūra ir kalba“ 1986, t. 19 , s. $65-66$.

30 Dz. cyt., s. 113. 
Dzisiejsze rozprawy nie ukazują całości wielowarstwowej spuścizny pisarza. W literaturoznawstwie polskim potrzebna jest synteza naukowa dzieła Baranauskasa.

\section{Bibliografia}

Aleksandravičius E., Giesmininko kelias, Vilnius 2003.

Baranauskas A., Raštai VII/1, Vilnius 2003.

Daujotytè V., A. Baranauskas - lyrikas, [w:] Literatūra ir kalba, t. 19, Vilnius 1986.

Jackiewicz M., Literatura polska na Litwie XVI-XX wieku, Olsztyn 1993.

Jackiewicz M., Polskojęzyczna twórczość biskupa Antanasa Baranauskasa, „Acta Polono-Ruthenika" 1997, nr 2.

Karaś H., Uwagi o polszczyźnie „Dzienników“ (1853-1856) Antanasa Baranauskasa, „Archivum Lithuanicum” 2004.

Kubilius V., Antanas Baranauskas ir lietuviu poezija, [w:] Literatūra ir kalba, t. 19, Vilnius 1986.

Mikšytè R., Antanas Baranauskas, Kaunas 1983.

Mikšytè R., Antano Baranausko kūryba, Vilnius 1964.

Subačius P., Antanas Baranauskas, Vilnius 2010.

Valentas S., Anykszcziu szilelys - Rytu Lietuvos tekstas: Šventumo erdvè, [w:] Lingvistinis pasaulis poezijoje, Vilnius 1997.

Zinkevičius Z., A. Baranauskas kalbininkas, [w:] Literatūra ir kalba, t. 19, Vilnius 1986. 